\title{
Prevalence of ABO and Rhesus Blood Groups in Northern India
}

\section{Tulika Chandra ${ }^{1 *}$ and Ashish Gupta ${ }^{1,2}$}

${ }^{1}$ Department of Transfusion Medicine, King George's Medical University, Lucknow, Uttar Pradesh, India

${ }^{2}$ Department of Pathology, King George's Medical University, Lucknow, Uttar Pradesh, India

\begin{abstract}
Background: The ABO blood group system was the first human blood group system to be discovered by Landsteiner in 1900. The second type of blood group is the rhesus system. There are only two Rh phenotype such as Rh positive and Rh negative, depending on whether Rh antigen is present on the red cell or not. The frequency of $A B O$ and Rh phenotypes in different populations has been extensively studied. The present study was done to assess the prevalence of blood groups in different categories of Northern India and to compare our results with other studies conducted in India and else where in the world and its multipurpose future utilities for the health planners.
\end{abstract}

Methods: A retrospective study was carried out on 23,320 blood donors during a period of one year from $1^{\text {st }}$ January to $31^{\text {st }}$ December 2011 . The Blood samples were obtained by standard procedures of venupuncture and subjected to determination of $A B O$ and Rhesus blood group using antisera by combined slide and test tube method. Each sample of donors was tested for $A B O$ and Rhesus status.

Results: The blood group B (34.84\%) was the commonest group prevalent in donors followed by group $\mathrm{O}$ (29.75\%), $A(21.50 \%)$ and $A B(13.91 \%)$. AB negative was not seen in female donors. $4.55 \%$.

Conclusion: The commonest $\mathrm{ABO}$ blood group was group $\mathrm{B}$ in Northern India with Rh negativity at only

Keywords: Blood donor; Commonest group; Distribution; Country; India

\section{Introduction}

The ABO blood group system was the first human blood group system to be discovered by Landsteiner in 1900. The ABO blood group system is the only system in which antibodies are consistently and predictably present in the serum of normal individuals whose red cells lack the antigens [1]. Apart from differences amongst species, differences between the individuals of the same species have also been demonstrated. During the World wars, it was discovered for the first time that the frequency of $\mathrm{ABO}$ and Rhesus blood groups was different in persons native to different parts of the world. Attempts have been made to classify the racial groups of mankind according to the incidence of known blood groups [2]. The second type of blood group is the rhesus system. There are only two Rh phenotype such as $\mathrm{Rh}$ positive and $\mathrm{Rh}$ negative, depending on whether Rh antigen is present on the red cell or not. Determination of $\mathrm{ABO}$ blood groups is done by detecting $A$ and $B$ antigens. In addition, known red cells are used to detect anti-A and anti-B in the serum, by a process called 'reverse' grouping. $\mathrm{ABO}$ and $\mathrm{Rh}$ gene phenotypes vary widely across races and geographical boundaries [3-5] despite the fact that the antigens involved are stable throughout life. The resultant polymorphism remains important in population genetic studies, estimating the availability of compatible blood, evaluating the probability of hemolytic disease in the new born, resolving disputes in paternity/maternity and for forensic purposes [6,7]. The frequency of $\mathrm{ABO}$ and $\mathrm{Rh}$ phenotypes in different populations has been extensively studied. Different blood groups have been shown to be particularly associated with different diseases as well $[8,9]$. Rh system emerged as second most important blood group system due to hemolytic disease of newborn and its importance in $\mathrm{RhD}$ negative individuals in subsequent transfusions once they develop $\mathrm{Rh}$ antibodies [1]. The D antigen, after A and B, is the most important red cell antigen in transfusion practice. Unlike the situation with A and B, persons whose red cell lacks the $\mathrm{D}$ antigen do not regularly have anti $\mathrm{D}$ in their serum. Blood bank usually has a problem of ever-changing stock position and it being very difficult to predict the prevalence of a particular blood group at a particular time. The present study was done to assess the prevalence of blood groups in different categories of Northern India and to compare our results with other studies conducted in India and elsewhere in the world and its multipurpose future utilities for the health planners.

\section{Material and Methods}

A retrospective study was carried out on 23,320 blood donors (male and female) during a period of one year from $1^{\text {st }}$ January to $31^{\text {st }}$ December 2011 in the State Blood Bank, Department of Transfusion Medicine, King George's Medical University, Lucknow, India. The blood donors were selected after taking a detailed history and a complete examination regarding their eligibility criteria for blood donation. Donor's name, age, sex, occupation, caste, complete postal address and contact number was taken. Donors were deferred or accepted according to their medical history regarding chronic or acute diseases. Findings were further confirmed by physical examination of the patient. Blood was taken from a donor only after fulfilling all the eligibility criteria of a healthy donor. Blood was taken for donors who were between 18-60 years of age, more than $50 \mathrm{~kg}$ weight with hemoglobin more than $12.5 \mathrm{~g} \%$. The donors have no history of any

*Corresponding author: Tulika Chandra, Department of Transfusion Medicine, King George's Medical University, Lucknow, Uttar Pradesh, India, Tel: +919415755536; E-mail: tulikachandra@rediffmail.com

Received October 03, 2012; Accepted October 23, 2012; Published October 25 , 2012

Citation: Chandra T, Gupta A (2012) Prevalence of ABO and Rhesus Blood Groups in Northern India. J Blood Disorders Transf 3:132. doi:10.4172/21559864.1000132

Copyright: (c) 2012 Chandra T, et al. This is an open-access article distributed under the terms of the Creative Commons Attribution License, which permits unrestricted use, distribution, and reproduction in any medium, provided the original author and source are credited. 
disease, infection or recent treatment. Written consent was also taken from them prior to donation regarding their acceptability for the tests to be carried out for the transfusion transmitted diseases.

The Blood samples were obtained by standard procedures of venupuncture and subjected to determination of $\mathrm{ABO}$ and Rhesus blood group using antisera (Eryscreen Monoclonal $\mathrm{ABO} / \mathrm{Rh}$, Tulip Diagnostic Ltd. Goa, India) by combined slide and test tube method. Each sample of donors was tested for $\mathrm{ABO}$ and Rhesus status.

\section{Ethical Issue}

The donors signed an informed consent after being informed that the details of their blood groups will remain with blood bank and may be used either for research or transfusion purposes. This is a routine procedure and has been approved ethically by the drug licensing authorities of India. Documentation is an integral part of blood banking and the use of data for research purposes have been advocated, keeping the donors identity hidden. This study was carried out within the acceptable ethical norms.

\section{Results}

The frequency of $\mathrm{ABO}$ and $\mathrm{Rh}$ blood groups in a total of 23,320 male and female donor population was compared (Table 1). Amongst Rh positive male donors blood group B was found to be most prevalent group (34.76\%) followed by group O (29.57\%), A (21.60\%) and $\mathrm{AB}$ (14.06\%). Amongst Rh positive female donors again blood group B was most common (35.29\%) followed by group O (29.41\%), A $(20.58 \%)$ and $\mathrm{AB}(14.70 \%)$. Rh negative donors were 1060 (4.55\%) amongst the total donors. On further analysis female donors showed a relatively higher incidence of $\mathrm{Rh}$ negativity (10.53\%) as compared to male (4.54\%) (Table 2). Among Rh negative male, blood group B (36.55\%) was the commonest followed by group O (33.23\%), A (19.41\%) and $\mathrm{AB}(10.79 \%)$ whereas in $\mathrm{Rh}$ negative females, blood group $\mathrm{B}(50 \%)$ was followed by $\mathrm{O}$ and $\mathrm{A}$ ( $25 \%$ each). None of the female donors showed $\mathrm{AB}$ negative. The total of ABO blood group was group B (34.84\%) followed by group $\mathrm{O}(29.75 \%)$ group $\mathrm{A}(21.50 \%)$ and group $\mathrm{AB}(13.91 \%)$.

\section{Discussion}

Research on $\mathrm{ABO}$ group system has been of immense interest, due

\begin{tabular}{|c|c|c|c|c|c|}
\hline & \multicolumn{2}{|c|}{ Male } & \multicolumn{2}{c|}{ Female } & \\
\hline $\begin{array}{c}\text { Blood } \\
\text { Group }\end{array}$ & $\begin{array}{c}\text { No. of Rh } \\
\text { positive (\%) }\end{array}$ & $\begin{array}{c}\text { No. of Rh } \\
\text { negative (\%) }\end{array}$ & $\begin{array}{c}\text { No. of Rh } \\
\text { positive (\%) }\end{array}$ & $\begin{array}{c}\text { No. of Rh } \\
\text { negative (\%) }\end{array}$ & Total \\
\hline B & $\begin{array}{c}7726 \\
(34.76 \%)\end{array}$ & $386(36.55 \%)$ & $12(35.29 \%)$ & $2(50 \%)$ & $\begin{array}{c}8126 \\
(34.84 \%)\end{array}$ \\
\hline O & $\begin{array}{c}6574 \\
(29.57 \%)\end{array}$ & $351(33.23 \%)$ & $10(29.41 \%)$ & $1(25 \%)$ & $\begin{array}{c}6936 \\
(29.75 \%)\end{array}$ \\
\hline A & $\begin{array}{c}4801 \\
(21.60 \%)\end{array}$ & $205(19.41 \%)$ & $7(20.58 \%)$ & $1(25 \%)$ & $\begin{array}{c}5014 \\
(21.50 \%)\end{array}$ \\
\hline AB & $\begin{array}{c}3125 \\
(14.06 \%)\end{array}$ & $114(10.79 \%)$ & $5(14.70 \%)$ & $0($ Nil) & $\begin{array}{c}3244 \\
(13.91 \%)\end{array}$ \\
\hline $\begin{array}{c}\text { Grand } \\
\text { Total }\end{array}$ & 22226 & 1056 & 34 & 4 & $\mathbf{2 3 3 2 0}$ \\
\hline
\end{tabular}

Table 1: Distribution of $\mathrm{ABO}$ and Rh blood groups between male and female.

\begin{tabular}{|c|c|c|c|}
\hline Gender & $\begin{array}{c}\text { No. of blood } \\
\text { donors (\%) }\end{array}$ & $\begin{array}{c}\text { No. of Rh positive } \\
\text { blood donors (\%) }\end{array}$ & $\begin{array}{c}\text { No. of Rh negative } \\
\text { blood donors (\%) }\end{array}$ \\
\hline Male & $23282(99.84 \%)$ & $22226(95.46 \%)$ & $1056(4.54 \%)$ \\
\hline Female & $38(0.16 \%)$ & $34(89.47 \%)$ & $4(10.55 \%)$ \\
\hline Total & 23320 & $22260(95.45 \%)$ & $1060(4.55 \%)$ \\
\hline
\end{tabular}

Table 2: Comparison of Rh positive and Rh negative (\%) between male and female donors. to its medical importance in different diseases. The $\mathrm{ABO}$ blood group system is not only important in blood transfusions, cardiovascular diseases, organ transplantation, erthroblastosis in neonates, but also one of the strongest predictors of national suicide rate and a genetic marker of obesity [10,11]. A significant deficit of group $\mathrm{O}$ has suggested that there may be susceptibility to develop osteoarthrosis in normal hip-joint and spinal osteochondrosis $[12,13]$. The genetic history of a person can be known by studying the blood groups [14]. In our study the $\mathrm{ABO}$ blood groups and $\mathrm{Rh}$ positivity in male and female donors showed that the blood group $B$ positive was most prevalent in both male and female followed by group $\mathrm{O}, \mathrm{A}$ and $\mathrm{AB}$. In contrast, the blood group $\mathrm{O}$ is the most prevalent group in Egypt [15]. Likewise blood group A in Russian Federation [16]. The commonest groups in Australians are $\mathrm{O}$ and $\mathrm{A}$ while in Africans $\mathrm{B}$ group is commonest [17]. In USA, $46 \%$ show group $\mathrm{O}, 41 \%$ group $A, 9 \%$ group $B$ and $4 \%$ group AB [18]. In Saudi Arabia, 52\% are group O, 25\% group A, 19\% group B and $4 \%$ group $\mathrm{AB}[19]$. According to an Iranian study blood group $\mathrm{O}$ is the most common group (41.16\%) over there [20].

India is a country with a lot of diversity based on race, religion and creed. Hence diversity has been observed in the distribution of blood groups in population within the country. Study from South India showed that blood group O was commonest (38.75\%) followed by group B (32.69\%), group A (18.85\%) and AB (5.27\%) [21]. Similarly studies in Karnataka, Jammu and Kashmir also showed $\mathrm{O}$ to be commonest $\mathrm{ABO}$ group in their population [22,23]. These results were different from our study where B group was commonest. Our study represented mainly Uttar Pradesh populations which focus as the highest populated state of Northern India. Further we observed that none of the female donors were $\mathrm{AB}$ negative. In contrast a Swat (Pakistan) study showed

\section{Percentage of Rh positive and negative}

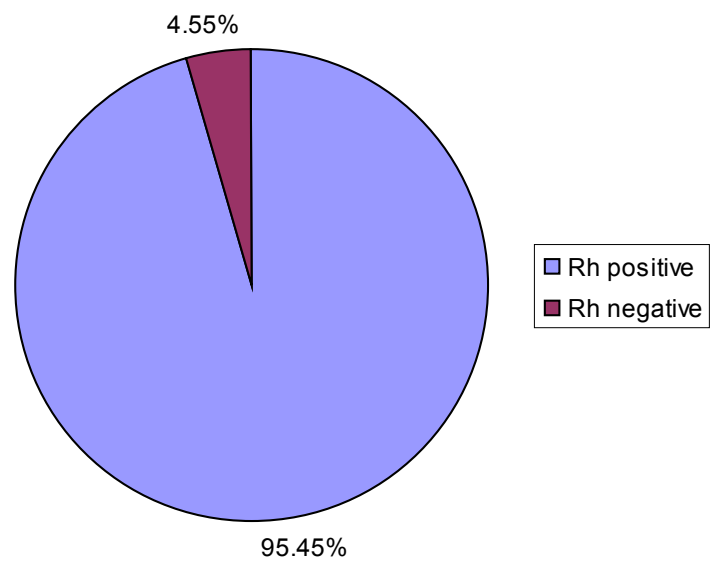

Figure 1: Percentage of Rh Positive and Negative blood donors

\begin{tabular}{|c|c|c|c|c|c|c|}
\hline Countries & $\mathbf{A}$ & $\mathbf{B}$ & $\mathbf{O}$ & $\mathbf{A B}$ & $\mathbf{R h}^{+}$ & $\mathbf{R h}^{-}$ \\
\hline $\begin{array}{c}\text { North India (Present } \\
\text { Study) }\end{array}$ & 21.50 & 34.84 & 29.75 & 13.91 & 95.45 & 4.55 \\
\hline Britain & 41.70 & 8.60 & 46.70 & 3.00 & 83.00 & 17.00 \\
\hline USA & 41.00 & 9.00 & 46.00 & 4.00 & 85.00 & 15.00 \\
\hline Nigeria & 24.43 & 23.88 & 48.94 & 2.75 & 95.67 & 4.33 \\
\hline Kenya & 26.20 & 22.00 & 47.48 & 4.32 & 96.10 & 3.90 \\
\hline Saudi Arabia & 25.00 & 19.00 & 52.00 & 4.00 & 93.00 & 7.00 \\
\hline Bangladesh & 26.6 & 23.2 & 40.6 & 9.6 & 96.8 & 3.2 \\
\hline
\end{tabular}

Table 3: Comparison of distribution (\%) of $\mathrm{ABO}$ and $\mathrm{Rh}$ blood groups in different countries of the world. 
that the blood group $\mathrm{AB}$ negative was $0.92 \%$ in female donors [24]. This discrepancy may be due to the small number of negative donors included in our study.

In Rhesus System, our study shows prevalence of Rh positive was $95.45 \%$, while only was $4.55 \%$ was Rh negative (Figure 1 ). These figures are similar to other studies carried out in Maharashtra, India [25,26]. Our donor population showed Rh negativity of $4.55 \%$ as compared to $17 \%$ in Britain. This suggests that the expected frequency of $\mathrm{Rh}$ isoimmunization would be lower in our population than that encountered in the Britain population. Similar incidences of $\mathrm{Rh}$ negative donors from other countries are as follows e.g. Nairobi (5\%), Nigeria (4.33\%), and Bangladesh (3.2\%) [27-29]. Rh positivity in our population was $95.45 \%$ which was almost similarly to Nigeria where Rh positivity was $95.67 \%$ [28]. In contrast, USA showed Rh positivity of $85 \%$. Rh positive group though the predominant group all over the country has a varied distribution in USA and UK as compared to other parts of the world (Table 3).

\section{Conclusion}

To conclude, the commonest $\mathrm{ABO}$ blood group was group $\mathrm{B}$ in Northern India with Rh negativity at only $4.55 \%$. This was in contrast to the prevalence of $\mathrm{ABO}$ and $\mathrm{Rh}$ blood groups in other parts of the world as well as also within the country.

\section{References}

1. Lo YM, Hjelm NM, Fidler C, Sargent IL, Murphy MF, et al. (1998) Prenata diagnosis of fetal RhD status by molecular analysis of maternal plasma. N Engl J Med 339: 1734-1738.

2. Boyd WC (1958) Genetics and the races of man. Boston. Little Brown 335-342.

3. Lasky LC, Lane TA, Miller JP, Lindgren B, Patterson HA, et al. (2002) In utero or ex utero cord blood collection: which is better? Transfusion 42: 1261-1267.

4. Wall DA, Noffsinger JM, MueckI KA, Alonso JM 3rd, Regan DM, et al. (1997) Feasibility of an obstetrician-based cord blood collection network for unrelated donor umbilical cord blood banking. J Matern Fetal Med 6: 320-323.

5. Dhot PS, Nair V, Swarup D, Sirohi D, Ganguli P (2003) Cord blood stem cell banking and transplantation. Indian J Pediatr 70: 989-992.

6. Armitage S, Warwick R, Fehily D, Navarrete C, Contreras M (1999) Cord blood banking in London: the first 1000 collections. Bone Marrow Transplant 24: 139145.

7. Solves P, Mirabet V, Larrea L, Moraga R, Planelles D, et al. (2003) Comparison between two cord blood collection strategies. Acta Obstet Gynecol Scand 82: 439-442.

8. AIRD I, BENTALL HH, ROBERTS JA (1953) A relationship between cancer of stomach and the ABO blood groups. Br Med J 1: 799-801.

9. Mollison PL, Engelfriet CP, Conteras M (1993) Immunology of red cells. In Blood Transfusion in Clinical Medicine. (9thedn), Oxford, Blackwell 87-88.

10. Mollison PL (1979) Blood transfusion in clinical medicine. (6thedn), Blackwell Scientific Publication: Oxford, UK 239-666.

11. Hein HO, Suadicani P, Gyntelberg F (2005) The Lewis blood group--a new genetic marker of obesity. Int J Obes (Lond) 29: 540-542.

12. Lourie JA (1983) Is there an association between $A B O$ blood groups and primary osteoarthrosis of the hip? Ann Hum Biol 10: 381-383.

13. Ritsner MS, Shmidt IR, Shekhner IA, Gurkov laV, Stankov IA (1979) Analysis of the distribution of $A B O$ system blood groups among patients with spinal osteochondrosis syndromes. Zh Nevropatol Psikhiatr Im S S Korsakova 79: 409-413

14. Sokolov R (1993) Why We Eat What We Eat: How Columbus Changed the Way the World Eats, New York, Simon \& Schuster 1-50.

15. Bahaj AA (2003) $A B O$ and rhesus blood groups distribution in Hadhramout population. Hadh Studies and Res 4: 2-7.
16. Tomilin VV, Gurtovaia SV (1999) The incidence of finding ABO system antigens in the population of the Russian Federation. Sud Med Ekspert 42: 16-18.

17. Mollison PL, Engelfriet CP (1993) ABO, Lewis, li and P Groups. In: Blood Transfusion in Clinical Medicine. (9thedn), Oxford, Blackwell Scientific Publication 150-161.

18. Frances TF (2002) Blood groups (ABO groups). In: Common Laboratory and Diagnostic Tests. (3rdedn), Philadelphia, Lippincott 19-25.

19. Bashwari LA, Al-Mulhim AA, Ahmad MS, Ahmed MA (2001) Frequency of ABO blood groups in the Eastern region of Saudi Arabia. Saudi Med J 22: 10081012.

20. Marzban M, Kamali MS, Hosseinbasi T (1988) Blood groups of the people of Ahwaz, Iran. Anthropol Anz 46: 83-89.

21. Das PK, Nair SC, Harris VK, Rose D, Mammen JJ, et al. (2001) Distribution of $A B O$ and Rh-D blood groups among blood donors in a tertiary care centre in South India. Trop Doct 31: 47-48.

22. Periyavan S, Sangeetha SK, Marimuthu P, Manjunath BK, Seema DM (2010) Distribution of $A B O$ and Rhesus-D blood groups in and around Bangalore. Asian J Transfus Sci 4: 41.

23. Khan MN, Khaliq I, Bakhsh A, Akhtar MS, Amin-ud-Din M (2009) Distribution of $\mathrm{ABO}$ and $\mathrm{Rh} \mathrm{D}$ blood groups in the population of Poonch District, Azad Jammu and Kashmir. East Mediterr Health J 15: 717-721.

24. Khattak ID, Khan TM, Khan P, Shah SM, Khattak ST, et al. (2008) Frequency of $A B O$ and Rhesus blood groups in District Swat, Pakistan. J Ayub Med Coll Abbottabad 20: 127-129.

25. Giri PA, Yadav S, Parhar GS, Phalke DB (2011) Frequency of ABO and Rhesus Blood Groups: A Study from a Rural Tertiary Care Teaching Hospital in India. Int J Biol and Med Res 2: 988 -990.

26. Warghat NE, Sharma NR, Baig MM, Sharma SH, Pachalore GS (2011) ABO and $\mathrm{Rh}$ Blood Group distribution among Kunbis (Maratha) population of Amravati District, Maharashtra. Asiatic J Biotech Resource 2: 479-483.

27. Mwangi J (1999) Blood group distribution in an urban population of patient targeted blood donors. East Afr Med J 76: 615-618.

28. Omotade OO, Adeyemo AA, Kayode CM, Falade SL, Ikpeme S (1999) Gene frequencies of $A B O$ and $R h(D)$ blood group alleles in a healthy infant population in Ibadan, Nigeria. West Afr J Med 18: 294-297.

29. Talukder SI, Das RK (2010) Distribution of ABO and Rh Blood Groups among Blood Donors of Dinajpur District of Bangladesh. Dinajpur Med Col J 3: 55-58. 